\title{
Molecular characterization of Escherichia coli isolated from milk samples with regard to virulence factors and antibiotic resistance
}

\author{
Waleed Younis ${ }^{1}$ (D), Sabry Hassan² (i) and Hams M.A. Mohamed ${ }^{1}$ (D) \\ 1. Department of Microbiology, Faculty of Veterinary Medicine, South Valley University, Qena, 83523, Egypt; \\ 2. Department of Biology, College of Science, Taif University, P.O. Box 11099, Taif 21944, Saudi Arabia. \\ Corresponding author: Waleed Younis, e-mail: wkhrdr39@gmail.com \\ Co-authors: SH: hassan@tu.edu.sa,HMAM: drhams85@yahoo.com \\ Received: 06-04-2021, Accepted: 09-08-2021, Published online: 17-09-2021
}

doi: www.doi.org/10.14202/vetworld.2021.2410-2418 How to cite this article: Younis W, Hassan S, Mohamed HMA (2021) Molecular characterization of Escherichia coli isolated from milk samples with regard to virulence factors and antibiotic resistance, Veterinary World, 14(9): 2410-2418.

\begin{abstract}
Background and Aim: Raw milk is considered an essential source of nutrition during all stages of human life because it offers a valuable supply of protein and minerals. Importantly, milk is considered a good media for the growth and contamination of many pathogenic bacteria, especially food-borne pathogens such as Escherichia coli. Thus, the objective of this study was to characterize $E$. coli and detect its virulence factors and antibiotic resistance from raw milk samples.

Materials and Methods: Raw milk samples $(\mathrm{n}=100)$ were collected from different localities in Qena, Egypt, and investigated for the presence of $E$. coli using different biochemical tests, IMViC tests, serotyping to detect somatic antigen type, and molecularly by polymerase chain reaction (PCR) tests. The presence of different virulence and antimicrobial genes ( $h l y$, eae, stx1, stx2, blaTEM, tet $A(A)$, and tetB genes) in E. coli isolates was evaluated using PCR.

Results: The results demonstrated that 10 out of 100 milk samples were contaminated with $E$. coli. Depending on serology, the isolates were classified as O114 (one isolate), O27 (two isolates), O111 (one isolate), O125 (two isolates), and untypeable (five isolates) $E$. coli. The sequencing of partially amplified 16S rRNA of the untypeable isolates resulted in one isolate, which was initially misidentified as untypeable E. coli but later proved as Enterobacter hormaechei. Moreover, antibacterial susceptibility analysis revealed that nearly all isolates were resistant to more than 3 families of antibiotics, particularly to $\beta$-lactams, clindamycin, and rifampin. PCR results demonstrated that all E. coli isolates showed an accurate amplicon for the blaTEM and tetA(A) genes, four isolates harbored eae gene, other four harbored tet $B$ gene, and only one isolate exhibited a positive stx2 gene.
\end{abstract}

Conclusion: Our study explored vital methods for identifying E. coli as a harmful pathogen of raw milk using 16S rRNA sequencing, phylogenetic analysis, and detection of virulence factors and antibiotic-resistant genes.

Keywords: 16S rRNA, antibiotic, Escherichia coli, raw milk, serology, virulence.

\section{Introduction}

Escherichia coli is a facultative anaerobe and one of the normal inhabitants in the human and animal intestinal tracts [1]. However, the pathogenic strains of $E$. coli cause many diseases [2]. Recently, pathogenic $E$. coli strains have been categorized using different antibodies for perceiving surface antigens correlated to "183 O-groups (lipopolysaccharide) and $53 \mathrm{H}$-types (flagellar antigen)" [3]. E. coli is differentiated into several pathotypes such as enterotoxigenic E. coli (ETEC) (O27), enterohemorrhagic E.coli (EHEC) (O111), and enteropathogenic E.coli (EPEC)" [4]. In general, these pathotypes encode genes for specific virulence factors that are associated with the attachment and secretion of hemolysins and enterotoxins; however, there is a significant

Copyright: Younis, et al. Open Access. This article is distributed under the terms of the Creative Commons Attribution 4.0 International License (http://creativecommons.org/licenses/by/4.0/), which permits unrestricted use, distribution, and reproduction in any medium, provided you give appropriate credit to the original author(s) and the source, provide a link to the Creative Commons license, and indicate if changes were made. The Creative Commons Public Domain Dedication waiver (http://creativecommons.org/ publicdomain/zero/1.0/) applies to the data made available in this article, unless otherwise stated. polymorphism presenting the nucleotide sequences of these genes [5].

Dissimilar strains of pathogenic E. coli produce several effective toxins, such as Shiga-like toxins. These Shiga toxin-producing E. coli (STEC) contribute toward gastroenteritis, bloody diarrhea, and uremic syndrome in infected humans [6]. Other virulence factors elevate the pathogenicity of $E$. coli combined with plasmid-encoded enterohemolysin ( hlyA), which is frequently associated with acute sickness in individuals [7], and also with intimin (eaeA), which is responsible for attachment, adherence, and clustering epithelial cell surfaces [8]. Polymerase chain reaction (PCR) analysis has detected that all strains of E. coli possess these virulence genes. However, the procurement of one or more virulence genes does not place bacteria in a harmful grade if that strain has not harbored the proper virulence gene that initiates disease in specific species [9]. "The dispersal of antibacterial resistance genes has been noticed between E. coli isolates from human, animal, and environmental sources." Antimicrobial resistance has been observed as a severe problem worldwide [10]. However, the incidence rates for antibiotic-resistant $E$. coli strains 
diverge in different environments [10]. Many authors have suggested that the extensive administration of penicillin, tetracyclines, and other sulfa drugs has contributed to the spread of antimicrobial-resistant $E$. coli, specifically those from animal sources [11].

Therefore, the main objectives of this study are to apply a broader array of virulence and antimicrobial-resistant genes that are known to arise in different pathotypes of $E$. coli while causing several diseases and to optimize uniplex PCR assays for their detection in milk samples.

\section{Material and Methods}

Ethical approval

The study was approved by the Animal Ethics Committee for Veterinary Research, Faculty of Veterinary Medicine, South Valley University, Qena, Egypt.

\section{Study period, location, and detection of $E$. coli in raw milk samples}

The study was conducted from February to August 2019. A total of 100 milk samples were collected from different sources (47 samples from dairy farms, 27 samples from retail markets, and 26 samples from farmers' houses) in Qena, Egypt. These samples were collected under aseptic conditions in a clean, sterile $15 \mathrm{~mL}$ falcon tube and transferred instantly in an icebox to the bacteriological laboratory in the Department of Microbiology, Faculty of Veterinary Medicine, South Valley University. One milliliter of milk samples were fed in $9 \mathrm{~mL}$ buffer peptone water (Oxoid) and incubated at $37^{\circ} \mathrm{C}$ for $18-24 \mathrm{~h}$. Subsequently, a sterile loop was used to transfer bacteria from the inoculated buffer peptone water and was inoculated on a MacConkey agar plate (Oxoid). Plates were incubated at $37^{\circ} \mathrm{C}$ for $24 \mathrm{~h}$. The suspected colonies were inoculated in eosin methylene blue (Oxoid). After the procedure, green metallic sheen colonies were selected for biochemical identification using the IMViC reaction and triple sugar iron test [12].

\section{Serology of $E$. coli isolates}

$E$. coli isolates were serogrouped according to a previous study [13]. The serotyping of $E$. coli isolates was performed by commercially available kits $(E$. coli antisera set 1 for O-antigen, Denka Seiken, Japan), which combined 8 polyvalent sera and 43 monovalent sera.

\section{Antibiotic susceptibility evaluation of bacterial} strains

Antimicrobial susceptibility tests were conducted using the disk diffusion method following the guidelines of a previous research [14]. A ruler premeditated the diameter of the inhibition zone. The sensitivity of each isolate was determined against 12 different antibiotics: Oxacillin $(1 \mu \mathrm{g})$, trimethoprim $(5 \mu \mathrm{g})$, tetracycline $(30 \mu \mathrm{g})$, sulfamethoxazole-trimethoprim $(1.25-23.75 \mu \mathrm{g})$, gentamicin $(10 \mu \mathrm{g})$, erythromycin $(15 \mu \mathrm{g})$, chloramphenicol $(30 \mu \mathrm{g})$, penicillin $\mathrm{G}$
$(10 \mu \mathrm{g})$, nalidixic acid $(30 \mu \mathrm{g})$, nitrofurantoin $(30 \mu \mathrm{g})$, clindamycin $(10 \mu \mathrm{g})$, and rifampin $(30 \mu \mathrm{g})$ (Oxoid).

\section{DNA extraction}

DNA extraction was performed using the QIAamp DNA Mini kit (Qiagen GmbH, Germany) with changes to the manufacturer's recommendations. Briefly, $10 \mu \mathrm{L}$ of proteinase $\mathrm{K}$ and $200 \mu \mathrm{L}$ of lysis buffer were added to $200 \mu \mathrm{L}$ of the bacterial suspension, and this mixture was then incubated at $56^{\circ} \mathrm{C}$ for $10 \mathrm{~min}$. After incubation, the lysate was mixed with $200 \mu \mathrm{L}$ of $100 \%$ ethanol. The mixture was then rinsed and centrifuged after the manufacturer's recommendations. Nucleic acid was washed with $100 \mu \mathrm{L}$ of elution buffer accompanied within the kit.

\section{Detection of 16S rRNA gene}

The extracted bacterial DNA and controls were amplified with $12.5 \mu \mathrm{L}$ of Emerald Amp Max PCR Master Mix (Takara, Japan), $1 \mu \mathrm{L}$ of each primer (20 pmol concentration), $6 \mu \mathrm{L}$ of DNA template, and 4.5 $\mu \mathrm{L}$ of water to reach a final volume of $25 \mu \mathrm{L}$. DNA was amplified (Table-1) in a thermal cycler (Applied Biosystem 2720, California, USA). PCR products were isolated on $1.5 \%$ of agarose gel, and DNA amplicons were visualized with ethidium bromide.

\section{The sequence of partial amplified 16S rRNA gene of untypeable $E$. coli strains}

Purified PCR products of partially amplified $16 \mathrm{~S}$ $r R N A$ of untypeable E. coli strains were sequenced in the forward and reverse directions, as well as in separate reactions, using primers of $16 \mathrm{~S}$ rRNA, according to the manufacturer's protocol using the following kits: Big Dye Terminator V.3.1 Cycle sequencing kit (Applied Biosystems), the sequencing cycle purification kit, DyeEx 2.0 Spin kit (Qiagen), and Hi-Diionized formamide (Applied Biosystems). DNA sequences were obtained from the Applied Biosystems 3130 (Tokyo, Japan). All the obtained 16S rRNA gene sequences were submitted to the GenBank. The multiple alignment algorithms in MegAlign (Dnastar, Window version 3.12e) were used to perform the sequence alignment of isolates.

\section{Phylogenetic analysis}

A phylogenetic tree, which relied on the $16 S$ $r R N A$ gene nucleotide sequence, was a tribute for the untypeable isolates to demonstrate these isolates' identities and reference strains logged in GenBank using MegAlign from the Lasergene package version 7 (Dnastar).

\section{Virulence genes in $\boldsymbol{E}$. coli strains Uniplex PCR}

Primers for the following genes $h l y$, eaeA, blaTEM, tetA $(A)$, and tet $B$ were used in a $25 \mu \mathrm{L}$ reaction containing $12.5 \mu \mathrm{L}$ of Emerald Amp Max PCR Master Mix (Japan), $1 \mu \mathrm{L}$ of each primer, $4.5 \mu \mathrm{L}$ of water, and $6 \mu \mathrm{L}$ of DNA template. The reaction was conducted in an Applied Biosystem 2720 thermal cycler (Table-1). 


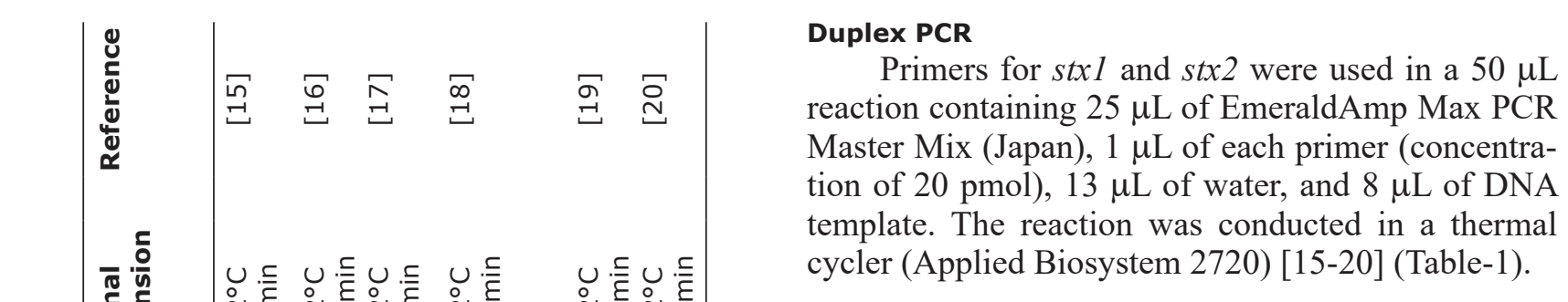

Investigation of the PCR products

The uniplex and duplex PCR products were separated by electrophoresis on $1.5 \%$ of agarose gel (AppliChem GmbH, Germany) in $1 \times$ TBE buffer at room temperature $\left(30^{\circ} \mathrm{C}\right)$ using a gradient of $5 \mathrm{~V} / \mathrm{cm}$. For gel analysis, $20 \mu \mathrm{L}$ of each product was loaded in each gel well. A 100 bp DNA ladder (Qiagen) was used to find out the amplicon sizes. The gel was visualized by a gel documentation system (Alpha Innotech, Biometra, Germany).

\section{Results}

We isolated from 10 out of 100 raw milk samples $(10 \%)$. Four samples were brought from markets, three samples were brought from dairy farms, and three samples were obtained from farmers' houses. The serology results of the $10 \mathrm{E}$. coli isolates from the raw milk samples, using antisera against the $\mathrm{O}$-antigen, exhibited that one isolate was O111, one isolate was $\mathrm{O} 27$, one isolate was $\mathrm{O} 114$, two isolates were $\mathrm{O} 125$, and the other five isolates were untypeable (Table-2).

The antibiotic susceptibility profile of the 10 E. coli isolates was determined against 12 different antibiotics according to Clinical Laboratory Standards Institute [14]. All 10 E. coli isolates did not show any sensitivity for oxacillin, penicillin, rifampin, and clindamycin. A total of nine isolates were resistant to erythromycin, and six isolates were resistant to trimethoprim. Moreover, five isolates were resistant to trimethoprim-sulfamethoxazole, chloramphenicol, nitrofurantoin, and gentamicin; furthermore, seven isolates did not have any zone of inhibition against tetracycline and four isolates were resistant to nalidixic acid. Four isolates were sensitive to both trimethoprim and trimethoprim-sulfamethoxazole. Three isolates were sensitive to chloramphenicol and nitrofurantoin.

Two isolates were resistant to tetracycline and gentamicin, whereas only one isolate was sensitive to erythromycin. Six isolates cleared intermediary susceptibility toward nalidixic acid, three isolates exhibited intermediate susceptibility to gentamicin, two isolates showed intermediary susceptibility toward chloramphenicol and nitrofurantoin, and only one isolate exhibited intermediary susceptibility toward trimethoprim-sulfamethoxazole and tetracycline (Table-2).

PCR results confirmed the presence of $E$. coli DNA in 10 isolates using housekeeping gene primers (16S rRNA). The presence of different virulence genes (hly, eaeA, stxl, and stx2) and antibiotic-resistant genes (blaTEM, tet $A(A)$, and tetB) was then evaluated in the 10 isolates (Table-3). 
Table-2: Antibiotic susceptibility analysis of Escherichia coli serogroups isolated from raw milk.

\begin{tabular}{|c|c|c|c|c|c|c|c|c|c|c|c|c|c|c|}
\hline \multirow[t]{2}{*}{ Samples } & \multirow{2}{*}{$\begin{array}{l}\text { Source of milk } \\
\text { sample }\end{array}$} & \multirow[t]{2}{*}{ Serogrouping } & \multicolumn{12}{|c|}{ Antimicrobial sensitivity } \\
\hline & & & $\mathbf{0}$ & SXT & TMP & C & TE & $\mathbf{F}$ & CN & $\mathbf{E}$ & $\mathbf{P}$ & NA & DA & RA \\
\hline 1 & Dairy farm & 0111 & $\mathrm{R}$ & $\mathrm{S}$ & I & I & I & $\mathrm{S}$ & I & $\mathrm{R}$ & $\mathrm{R}$ & I & $\mathrm{R}$ & $\mathrm{R}$ \\
\hline 2 & Retail market & 027 & $\mathrm{R}$ & $\mathrm{S}$ & $\mathrm{S}$ & $\mathrm{R}$ & $\mathrm{R}$ & $\mathrm{S}$ & I & $\mathrm{R}$ & $\mathrm{R}$ & I & $\mathrm{R}$ & $\mathrm{R}$ \\
\hline 3 & Retail market & Untypeable & $\mathrm{R}$ & $\mathrm{R}$ & $\mathrm{R}$ & $\mathrm{S}$ & $\mathrm{I}$ & $\mathrm{R}$ & $\mathrm{S}$ & $\mathrm{R}$ & $\mathrm{R}$ & $\mathrm{I}$ & $\mathrm{R}$ & $\mathrm{R}$ \\
\hline 4 & Dairy farm & Untypeable & $\mathrm{R}$ & $\mathrm{R}$ & I & $\mathrm{R}$ & I & $\mathrm{R}$ & $\mathrm{R}$ & $\mathrm{R}$ & $\mathrm{R}$ & $\mathrm{R}$ & $\mathrm{R}$ & $\mathrm{R}$ \\
\hline 5 & Dairy farm & Untypeable & $\mathrm{R}$ & $\mathrm{S}$ & $\mathrm{S}$ & $\mathrm{S}$ & $\mathrm{R}$ & $\mathrm{S}$ & $\mathrm{R}$ & $\mathrm{R}$ & $\mathrm{R}$ & $\mathrm{R}$ & $\mathrm{R}$ & $\mathrm{R}$ \\
\hline 6 & Farmer's house & Untypeable & $\mathrm{R}$ & $\mathrm{R}$ & $\mathrm{R}$ & $\mathrm{R}$ & $\mathrm{R}$ & $\mathrm{R}$ & $\mathrm{R}$ & $\mathrm{R}$ & $\mathrm{R}$ & $\mathrm{I}$ & $\mathrm{R}$ & $\mathrm{R}$ \\
\hline 7 & Farmer's house & 0114 & $\mathrm{R}$ & $\mathrm{R}$ & $\mathrm{R}$ & $\mathrm{R}$ & $\mathrm{R}$ & I & I & $\mathrm{R}$ & $\mathrm{R}$ & I & $\mathrm{R}$ & $\mathrm{R}$ \\
\hline 8 & Retail market & Untypeable & $\mathrm{R}$ & $\mathrm{R}$ & $\mathrm{R}$ & $\mathrm{S}$ & I & $\mathrm{R}$ & $\mathrm{S}$ & $\mathrm{R}$ & $\mathrm{R}$ & $\mathrm{I}$ & $\mathrm{R}$ & $\mathrm{R}$ \\
\hline 9 & Retail market & 0125 & $\mathrm{R}$ & $\mathrm{I}$ & $\mathrm{R}$ & $\mathrm{R}$ & $\mathrm{R}$ & $\mathrm{R}$ & $\mathrm{R}$ & $\mathrm{R}$ & $\mathrm{R}$ & $\mathrm{R}$ & $\mathrm{R}$ & $\mathrm{R}$ \\
\hline 10 & Farmer's house & 0125 & $\mathrm{R}$ & $\mathrm{S}$ & $\mathrm{S}$ & $\mathrm{R}$ & $\mathrm{R}$ & $\mathrm{R}$ & $\mathrm{R}$ & $\mathrm{R}$ & $\mathrm{R}$ & $\mathrm{I}$ & $\mathrm{R}$ & $\mathrm{R}$ \\
\hline
\end{tabular}

$\mathrm{S}=$ Sensitive, $\mathrm{R}=$ Resistant, $\mathrm{I}=$ Intermediate, $\mathrm{O}=$ Oxacillin, $\mathrm{SXT}=$ Sulfamethoxazole-trimethoprim, TMP=Trimethoprim, $\mathrm{C}=$ Chloramphenicol, $\mathrm{TE}=$ Tetracycline, $\mathrm{F}=$ Nitrofurantoin, $\mathrm{CN}=$ Gentamicin, $\mathrm{E}=$ Erythromycin, $\mathrm{P}=$ Penicillin, NA=Nalidixic acid, RA=Clindamycin, DA=Rifampin

Table-3: Molecular detection $16 S$ rRNA, virulence genes, and antimicrobial resistance gene for Escherichia coli isolates obtained from raw milk samples.

\begin{tabular}{|c|c|c|c|c|c|c|c|c|}
\hline \multirow[t]{2}{*}{ Sample } & \multicolumn{8}{|c|}{ Molecular detection } \\
\hline & $\begin{array}{c}16 S \\
\text { rRNA }\end{array}$ & eaeA & hly & $\operatorname{tx} 1$ & $\operatorname{tx} 2$ & $\begin{array}{c}\text { tetA } \\
\text { (A) }\end{array}$ & tetB & aTEM \\
\hline 1 & $+t$ & $-\neq$ & - & - & - & + & - & + \\
\hline 2 & + & - & - & - & - & + & - & + \\
\hline 3 & + & - & - & - & - & + & - & + \\
\hline 4 & + & + & - & - & + & + & + & + \\
\hline 5 & + & & - & - & - & + & + & + \\
\hline 6 & + & + & - & - & - & + & + & + \\
\hline 7 & + & - & - & - & - & + & - & + \\
\hline 8 & + & - & - & - & - & + & + & + \\
\hline 9 & + & + & + & - & - & + & - & + \\
\hline 10 & + & + & - & - & - & + & - & + \\
\hline
\end{tabular}

+ mean positive. $\neq$ mean negative

We found that two E. coli isolates $(\mathrm{O} 125)$ and two untypeable $E$. coli isolates were positive for the eaeA gene (Figure-1). Only one E. coli isolate $(\mathrm{O} 125)$ was positive for the hly gene (Figure-2). All 10 E. coli isolates were negative for the presence of $s t x 1$ and st $x 2$ genes, except for one untypeable E. coli isolate that was positive for stx2 (Figure-3). As it pertains to the presence of specific antibiotic-resistant genes, we found that all 10 isolates of $E$. coli were positive for the blaTEM (Figure-4) and tetA (A) (Figure-5). In addition, four untypeable $E$. coli isolates were positive for the $\operatorname{tet} B$ (Figure-6).

The partially amplified $16 S r R N A$ gene sequencing results confirmed that four untypeable isolates were of E. coli (Table-4). Interestingly, one isolate (number 5) originally classified as E. coli was determined to be a strain of Enterobacter hormaechei (Table-4) after subjecting this isolate's sequence to an NCBI Blast search. The neighbor-joining algorithm was used to generate a phylogenetic analysis using MegAlign from the Lasergene package version 7 (Dnastar). The phylogenetic trees, reconstructed from partially amplified $16 \mathrm{~S} r R N A$ gene sequences from the five untypeable $E$. coli isolates, were mainly the same altogether. Nevertheless, a slight variety was noticed

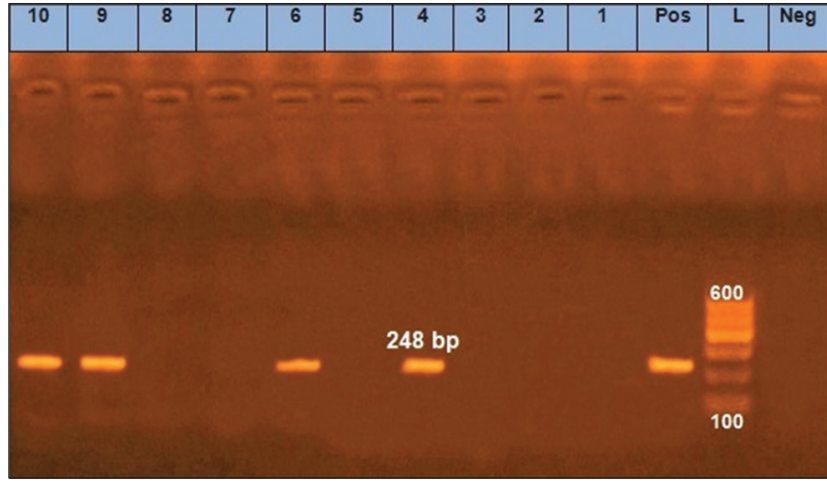

Figure-1: Gel image showing amplification of 248 bp product corresponding to the eaeA gene of $E$. coli serogroups isolated from raw milk. Lane (L): 100 bp DNA ladder; lane (Pos): positive control; lane (Neg): Negative control; lanes corresponding to milk samples 1-3, 5, 7, and 8 were negative while samples in lanes $4,6,9$, and 10 were positive.

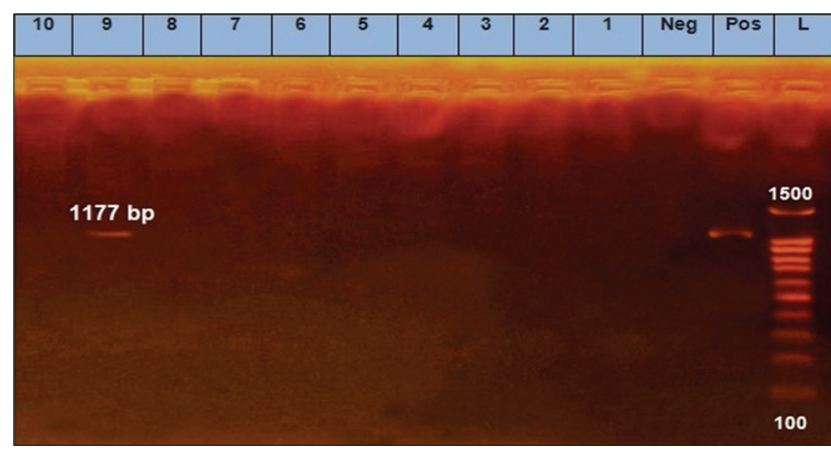

Figure-2: Gel image showing amplification of the 1177 bp band corresponding to the hyl gene of Escherichia coli serogroups isolated from raw milk samples. Lane (L): 100 bp DNA ladder; lane (Pos): Positive control; lane (Neg): Negative control; lanes corresponding to samples 1-8 and 10 were negative while lane 9 was positive.

in branching, as shown in Figure-7. The phylogenetic tree identified groups corresponding to species belonging to the same genus. Our isolates exhibited a high degree of similarity with one other (Figure-8), with similarity percentages ranging between $96.5 \%$ and $100 \%$. These isolates were registered on GenBank by accession number (Table-4). 
Table-4: Accession numbers of the untypeable Escherichia coli isolates.

\begin{tabular}{lllll}
\hline Isolate No. & Serological identification & Source & 16S rRNA sequencing & Accession number \\
\hline 1 & Untypeable E. coli & Retail market & Escherichia coli & MN064835 \\
2 & Untypeable E. coli & Dairy farm & Escherichia coli & MN064861 \\
3 & Untypeable E. coli & Dairy farm & Escherichia coli & MN06483 \\
4 & Untypeable E. coli & Farmer's house & Escherichia coli & MN066319 \\
5 & Untypeable E. coli & Retail market & Enterobacter hormaechei & MN066412 \\
\hline
\end{tabular}

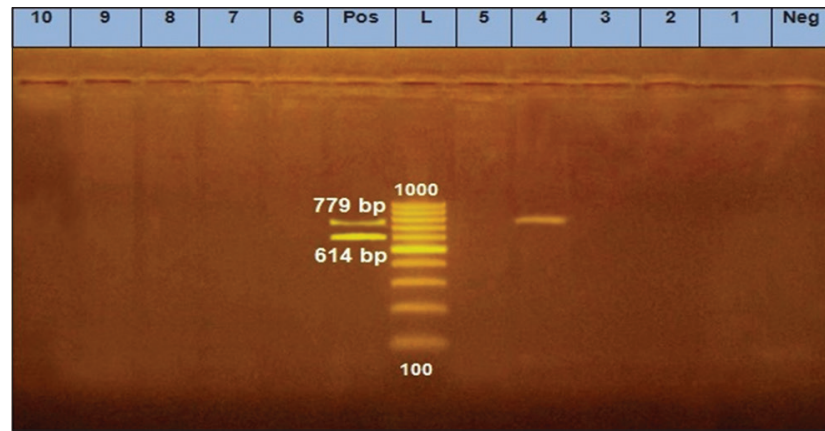

Figure-3: Gel image showing amplification of 614 and 779 bp products corresponding to the stx 1 and stx2 genes from $E$. coli isolated from raw milk samples. Lane (L): 100 bp DNA ladder; lane (Pos): Positive control; lane (Neg): Negative control; lanes corresponding to samples 1-10 were negative for the stx 1 gene. The milk samples in lane 4 were positive for the stx 2 gene while samples in lanes 1-3 and 5-9 were negative for the stx2 gene.

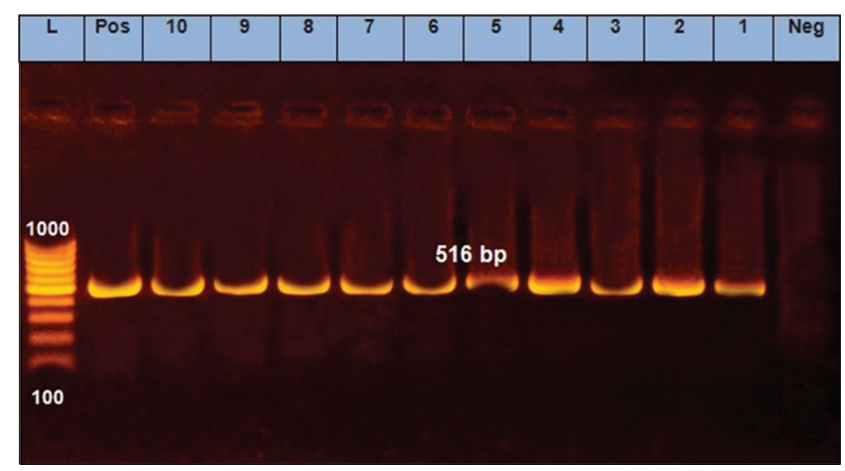

Figure-4: Polymerase chain reaction analysis for detection of the blaTEM gene ( 516 bp product) from $E$. coli isolated from raw milk samples. Lane (L): 100 bp DNA ladder; lane (Pos): Positive control; lane (Neg): Negative control; lanes (1-10) demonstrate that all $10 \mathrm{E}$. coli isolates were positive for the blaTEM gene.

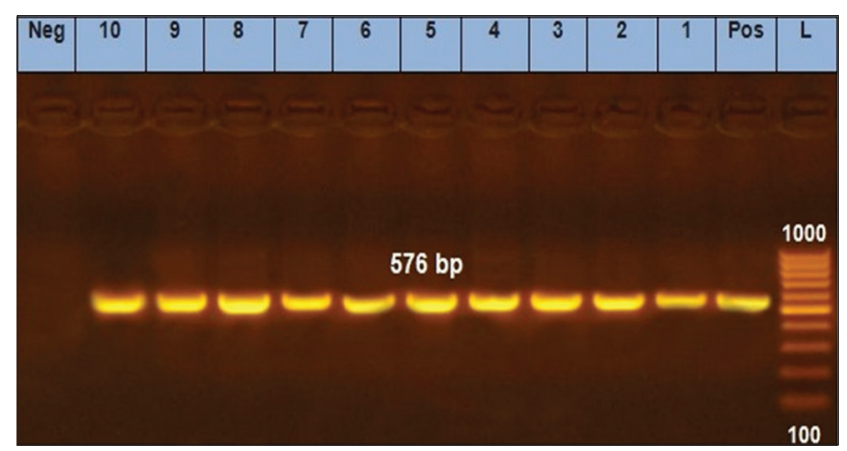

Figure-5: Polymerase chain reaction analysis for detection of the $\operatorname{tet} A(A)$ gene, amplification of 576 bp product, from $E$. coli isolated from raw milk samples. Lane (L): $100 \mathrm{bp}$ DNA ladder; lane (Pos): Positive control; lane (Neg): Negative control; lanes (1-10) demonstrate that all 10 $E$. coli isolates were positive for the $\operatorname{tet} A(A)$ gene.

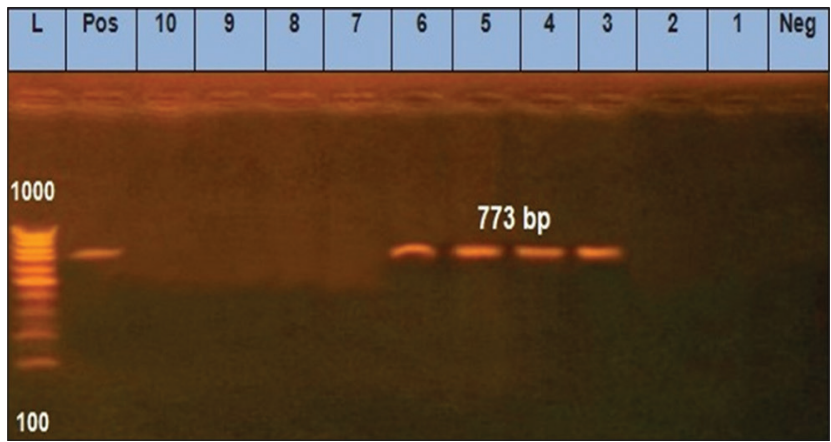

Figure-6: Polymerase chain reaction analysis for detection of the tet $B$ gene, amplification of the 773 bp product, from $10 \mathrm{E}$. coli isolated from raw milk samples. Lane (L): $100 \mathrm{bp}$ DNA ladder; lane (Pos): Positive control; lane (Neg): Negative control; samples in lanes (3-6) were positive while samples in lanes 1, 2, and 7-10 were negative.

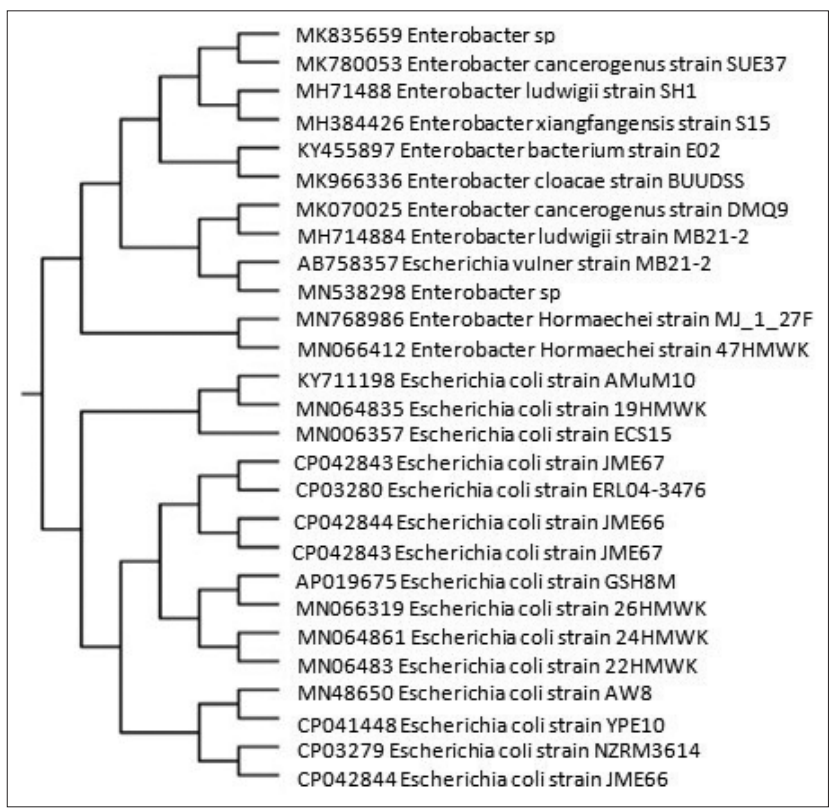

Figure-7: Neighbor-joining tree showing the $16 S$ rRNA gene phylogenetic relationships of the strains isolated from the raw milk samples and phylogenetically related reference strains from GenBank.

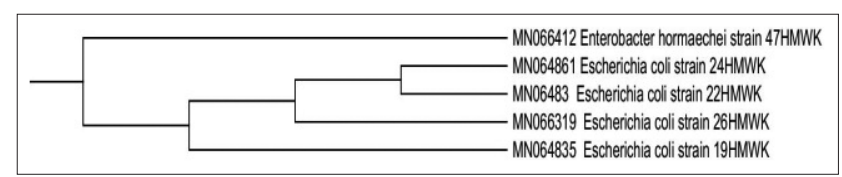

Figure-8: Neighbor-joining tree showing the $16 S$ rRNA gene phylogenetic relationships of the strains isolated from raw milk samples.

Furthermore, the degree of similarity and deviation was determined between our isolates and reference strains. Untypeable $E$. coli isolate 1 grouped with $E$. coli 
MN006357 and E. coli KY711198, with an identity percentage of $98.1 \%$. In addition, untypeable $E$. coli isolates 2, 3, and 4 grouped with E. coli (AP019675) with similarity percentages of $98.9 \%, 98.1 \%$, and $98.3 \%$, respectively. The last isolate identified phenotypically as E. coli (isolate 5) exhibited the most similarity $(98.4 \%$ identical) with E. hormaechei (MF768986) (Table-4).

\section{Discussion}

The phenotypic identification of raw milk samples revealed a concern with maintaining proper hygienic conditions at the sampling sites. Among the 100 milk samples collected, $10(10 \%)$ were contaminated with $E$. coli. These results are nearly similar to those of Kumar and Prasad [21], who found that $8.14 \%$ of the milk samples were contaminated with $E$. coli. da Silva et al. [22] isolated E. coli from $22.1 \%$ of milk samples in Brazil. Disassa et al. [23] isolated E. coli from 33.9\% of cow milk samples in Ethiopia. These studies share the same concern as our research that $E$. coli contamination of raw milk samples is a growing challenge.

The outer layer of $E$. coli features many lipopolysaccharides distinguished by the $\mathrm{O}$-antigen. The enucleating of the $\mathrm{O}$-antigen from the wall of bacterial cell attenuate bacterial pathogenicity in suggesting the $\mathrm{O}$-antigen, which plays a key role in host-pathogen interactions [24]. Correspondingly, O-antigens caused antigenic diversity among bacteria and besieged to be the biomarkers for the identification of $E$. coli since the 1940s [25]. Based on the serological analysis targeting the $\mathrm{O}$-antigen of the $10 \mathrm{E}$. coli isolates sampled from raw milk sources in our study, five isolates were serotyped as O111, O27, O114, and O125, and five strains were untypeable by agglutination. The identified isolates were differentiated according to a previous study [26] as enterotoxigenic $E$. coli (ETEC) (O27), enterohemorrhagic E. coli (O111), and enteropathogenic E. coli (EPEC) (O114 and O125). Our results are related to the results obtained by the previous studies $[27,28]$. Several authors have recorded a wide range of E. coli serogroups in cattle $[26,29,30]$. Pathogencity of EPEC isolates obtained from milk samples represented a potential risk for public health due to their linkage with infant diarrhea [31-33]. As stated earlier, in this study, five $E$. coli isolates were untypeable in the agglutination test. This highlights one of the challenges of serological methods, as discussed by Delannoy et al. [34] who found that the serological agglutination of the $\mathrm{O}$-antigens is difficult, time-consuming, and expensive. Besides, many samples remain untypeable by agglutination; consequently, molecular methods are better alternatives for O-typing [35].

The DNA sequencing of $16 \mathrm{~S}$ rRNA can aid in the identification of E. coli [36], especially in the cases of phenotypic misidentification as occurred with one isolate from the milk samples in our study. The serological evaluation indicated that one isolate was an untypeable $E$. coli strain but was later confirmed as an isolate of $E$. hormaechei (accession no. MN066412). Garbaj et al. [37] found that out of 27 E. coli strains identified using conventional methods, only 11 strains were confirmed to be $E$. coli using $16 \mathrm{~S}$ rRNA sequencing. This result suggests the importance of using molecular methods to validate the isolate information obtained from conventional serological techniques.

The additional appraisal of the 16S rRNA sequences of $E$. coli strains earned from milk samples by the neighbor-joining tree found that there was a high degree of similarity between our isolates (similarity of $95.5-100 \%$ ), as all of these species originated from the Enterobacteriaceae family [38]. The sequencing of $16 \mathrm{~S}$ rRNA further assisted in identifying the five untypeable strains by grouping these strains with GenBank-based reference strains. This analysis revealed that E. coli (MN064835) was related to two reference $E$. coli strains (MN006357 and KY711198). Both strains are uropathogenic E. coli (UPEC) strains [39]. Moreover, E. coli isolates MN066319, MN064861, and MN06483 were found to be related to a reference strain (E. coli AP019675), which is an extended-spectrum $\beta$-lactamase $E$. coli (ESBL) strain [40]. Most of the reference strains were isolated from patients and environmental samples (e.g., water and soil) $[39,40]$. Thus, finding similar E. coli isolates in raw milk are unsurprising. Nevertheless, this observation highlights the importance of performing a microbiological analysis of milk to verify that there is no public health risk to consume the milk. This is particularly important to curb the outbreaks of food-borne illnesses, which were formerly linked to the consumption of milk and dairy products that had been contaminated with pathogenic bacteria or their toxins [41].

STEC (Stx) strains were identified from cattle farms more than 3 decades ago. Studies implemented in several regions have shown that $10-80 \%$ of cattle may harbor STEC $[29,42,43]$. In this study, the stx 2 gene was found in only one isolate (untypeable E. coli), whereas the $s t x 1$ gene was not harbored by any of the 10 isolates. Our result matches the previous studies $[28,44]$ but differs from the results obtained by other studies $[45,46]$. Almost the equal distribution of stxl and stx2 was noted by Zschock et al. [47] in the fecal samples of E. coli obtained from cows. This may be attributed to the repeated turnover of serotypes of $E$. coli, with many being isolated only sporadically from a herd [48]. Furthermore, Jenkins et al. [49] confirmed that there is a dissimilarity in the percentage of $s t x$ genes detected, according to the distribution of STEC.

As it pertains to pathogenesis, E. coli utilizes various virulence factors to colonize and infect host cells. One factor is intimin (encoded by the eaeA gene), which plays an important role in the pathogenesis of attaching-and-effacing lesion, which facilitates the colonization of host tissues [50]. In our study, the eaeA gene was detected in four $E$. coli isolates $(40 \%)$. Two isolates were EPEC of serotype O125 and O114, and the other two isolates were untypeable E. coli. Many authors have previously revealed that EPEC strains harbor the eaeA gene $[51,52]$. The eaeA gene was detected in $4 \%$ of $E$. 
coli isolates in a previous study [46] and $25 \%$ of isolates in a study by Hussien et al. [53].

A second key virulence factor used by $E$. coli to promote pathogenesis is the liberation of hemolysin, a pore-forming cytolysin (encoded by the hlyCABD gene). In our study, we illustrated that only one isolate belonging to EPEC harbored the hly gene. EPEC strains, UPEC strains, ETEC strains, and STEC strains carried the hly gene, which is encoded on a plasmid reported by Burgos [54].

After evaluating the existence of genes encoding key virulence factors, we next assessed the antibiotic resistance profile of the $10 \mathrm{E}$. coli isolates obtained from the raw milk samples. The propagation of antibacterial resistance is the leading cause of many health problems worldwide. In this study, we found that a high percentage $(100 \%)$ of $E$. coli isolates were resistant to penicillin, oxytetracycline, doxycycline, rifampicin, trimethoprim/sulfamethoxazole, and tetracycline. Multidrug resistance (resistance to more than 3 classes of antibiotics) was also observed in several of our E. coli isolates. The isolation of multidrug-resis$\operatorname{tant} E$. coli isolates is not surprising as this phenotype has been reported for $E$. coli in other studies $[55,56]$. In addition, two studies have found that $E$. coli isolates obtained from milk samples were resistant to antibiotics, mainly to $\beta$-lactam antibiotics $[57,58]$.

Bacterial resistance to antibiotics may occur by an impulsive mutation in the target gene(s) due to using antibiotics in therapy or enhancing growth in animals. These antibiotic-resistant bacteria can be spread in the environment when infected animals defecate, thus contaminating soil and agricultural products. If the raw products are consumed, then the resistant bacteria may consequently colonize and infect humans [59]. Among the bacterial isolates obtained from the raw milk samples in this study, we found that genes conferring resistance to tetracycline $(\operatorname{tet} A(A)$ and $\operatorname{tet} B)$ were the most prevalent. This finding is concerning because tetracycline is one of the most important antibiotics used in Egypt [60,61].

In addition to resistance to tetracycline, the presence of ESBL's confers resistance to many antibiotics, such as aztreonam, related oxyimino- $\beta$-lactams, cephalosporins, and penicillin. There is a wide variety of ESBLs, including plasmid-mediated resistant to ampicillin, oxacillin, and cefotaxime [62]. The mechanism of drug efflux pumps and the existence of the outer membrane further obstruct the entry of antibiotics in Gram-negative bacterium such as E. coli. Focusing on ESBLs, in this study, the blaTEM gene was detected in all E. coli isolates. The prevalence of blaTEM found in our $E$. coli isolates matches results obtained by the previous studies $[63,64]$, who found that most of their E. coli isolate harbored blaTEM.

Our study demonstrated a relationship between the resistance to drugs and the presence of virulence factors. The attainment of antibiotic resistance and virulence factors in $E$. coli can arise through gene transfer in the environment or the human and animal guts. The genes can be found either on the same plasmid or separately on bacterial chromosomal DNA and plasmids. These genes might be coselected in response to antibiotic pressure, hence aggravating the hazard imposed by $E$. coli on food safety $[65,66]$.

\section{Conclusion}

According to this study's findings, E. coli is considered one of the most common food-borne pathogens that can be transmitted to humans by drinking raw milk. Some strains of $E$. coli harbor some virulent genes eae, hyl stx2 genes, antibiotic-resistant genes blaTEM, $\operatorname{tet} A(\mathrm{~A})$, and tet $B$. Furthermore, they showed marked resistance to several antibiotics commonly used in animals and humans in Egypt (MDR). Therefore, much more attention should be paid to hygienic measures during the milking process in dairy farms and the prudent use of antibiotics supported by antibiogram tests before drug administration in dairy farms.

\section{Authors' Contributions}

WY and HMAM: Designed the study, drafted and critically revised the manuscript, collected samples, and did laboratory works. SH: Revised the manuscript and interpretation of the data. All authors read and approved the final manuscript.

\section{Acknowledgments}

The study was funded by Taif University Researchers Supporting project (No. TURSP2020/142), Taif University, Taif, Saudi Arabia. We would like to thank Dr. Haroon Mohamed for his help in the editing of the manuscript.

\section{Competing Interests}

The authors declare that they have no competing interests.

\section{Publisher's Note}

Veterinary World remains neutral with regard to jurisdictional claims in published institutional affiliation.

\section{References}

1. Abd, A.A., Tawab, E., Ammar, A.M., Nasef, S.A. and Reda, R.M. (2015) Prevalence of $E$. coli in diseased chickens with its antibiogram pattern. Benha Vet. Med. J., 28(2): 224-230.

2. Ribeiro, L.F., Barbosa, M.M.C., Pinto, F.R., Lavezzo, L.F., Rossi, G.A.M., Almeida, H.M.S. and Amaral, L.A. (2019) Diarrheagenic Escherichia coli in raw milk, water, and cattle feces in non-technified dairy farms. Cienc. Anim. Bras., 20(1-9): e47449.

3. Joensen, K.G., Tetzschner, A.M.M., Iguchi, A., Aarestrup, F.M. and Scheutz, F. (2015) Rapid and easy in silico serotyping of Escherichia coli isolates by use of whole-genome sequencing data. J. Clin. Microbiol., 53(8): 2410-2426.

4. Debroy, C., Fratamico, P.M. and Roberts, E. (2018) Molecular serogrouping of Escherichia coli. Anim. Health Res. Rev., 19(1): 1-16.

5. Li, D., Shen, M., Xu, Y., Liu, C., Wang, W., Wu, J., Jia, X. and Ma, Y. (2018) Virulence gene profiles and molecular 
genetic characteristics of diarrheagenic Escherichia coli from a hospital in Western China. Gut Pathog., 10(1): 1-11.

6. Beutin, L., Marchés, O., Bettelheim, K.A., Gleier, K., Zimmermann, S., Schmidt, H. and Oswald, E. (2003) HEp-2 cell adherence, actin aggregation, and intimin types of attaching and effacing Escherichia coli strains isolated from healthy infants in Germany and Australia. Infect. Immun., 71(7): 3995-4002.

7. Chiou, Y.Y., Chen, M.J., Chiu, N.T., Lin, C.Y. and Tseng, C.C. (2010) Bacterial virulence factors are associated with occurrence of acute pyelonephritis but not renal scarring. $J$. Urol., 184(5): 2098-2102.

8. Berne, C., Ducret, A., Hardy, G.G. and Brun, Y.V. (2015) Adhesins involved in attachment to abiotic surfaces by gram-negative Bacteria. Microb. Biofilm., 3(4): 163-199.

9. Manage, D.P., Lauzon, J., Jones, C.M., Ward, P.J., Pilarski, L.M., Pilarski, P.M. and McMullen, L.M. (2019) Detection of pathogenic Escherichia coli on potentially contaminated beef carcasses using cassette PCR and conventional PCR. BMC Microbiol., 19(1): 1-11.

10. Doi, Y., Iovleva, A. and Bonomo, R.A. (2017) The ecology of extended-spectrum $\beta$-lactamases (ESBLs) in the developed world. J. Travel. Med., 24(1): S44-S51.

11. Schroeder, C.M., Zhao, C., DebRoy, C., Torcolini, J., Zhao, S., White, D.S., Wagner, D.D., McDermott, P.F., Walker, R.D. and Meng, J. (2002) Antimicrobial resistance of Escherichia coli O157 isolated from humans, Cattle, Swine, and food. Appl. Environ. Microbiol., 68(2): 576-581.

12. Quinn, P.J., Markey, B.K., Carter, M.E., Donnelly, W.J.C. and Leonard, F.C. (2002) Veterinary Microbiology and Microbial Diseases. $1^{\text {st }}$ ed. Iowa State University Press, Ames, Iowa, USA. p536.

13. Edward, P. and Ewing, W. (1972) Identification of Enterobacteriaceae. $3^{\text {rd }}$ ed. Bergcys Publishing Co., Minneapolis. p709.

14. CLSI. (2017) Performance Standards for Antimicrobial Susceptibility Testing. $27^{\text {th }}$ ed. CLSI Supplement M100, Wayne, PA.

15. Wang, G., Clark, C.G. and Rodgerst, F.G. (2002) Detection in Escherichia coli of the genes encoding the major virulence factors, the genes defining the O157:H7 serotype, and components of Type 2 shiga toxin family by multiplex PCR. J. Clin. Microbiol., 40(10): 3613-3619.

16. Piva, I.C., Pereira, A.L., Ferraz, L.R., Silva, R.S.N., Vieira,A.C., Blanco, J.E., Blanco, M., Blanco, J. and Giugliano, L.G. (2003) Virulence markers of enteroaggregative Escherichia coli isolated from children and adults with diarrhea in Brasília, Brazil. J. Clin. Microbiol., 41(5): 1827-1832.

17. Bisi-Johnson, M.A., Obi, C.L., Vasaikar, S.D., Baba, K.A. and Hattori, T. (2011) Molecular basis of virulence in clinical isolates of Escherichia coli and Salmonella species from a tertiary hospital in the Eastern Cape, South Africa. Gut Pathog., 3(1): 9.

18. Dipineto, L., Santaniello, A., Fontanella, M., Lagos, K., Fioretti, A. and Menna, L.F. (2006) Presence of shiga toxin-producing Escherichia coli O157:H7 in living layer hens. Lett. Appl. Microbiol., 43(3): 293-295.

19. Randall, L.P., Cooles, S.W., Osborn, M.K., Piddock, L.J.V. and Woodward, M.J. (2004) Antibiotic resistance genes, integrons and multiple antibiotic resistance in thirty-five serotypes of Salmonella enterica isolated from humans and animals in the UK. J. Antimicrob. Chemother., 53(2): 208-216.

20. Colom, K., Pérez, J., Alonso, R., Fernández-Aranguiz, A., Lariño, E. and Cisterna, R. (2003) Simple and reliable multiplex PCR assay for detection of BlaTEM, BlaSHV and BlaOXA-1 genes in enterobacteriaceae. FEMS Microbiol. Lett., 223(2): 147-151.

21. Kumar, R. and Prasad, A. (2010) Detection of E. Coli and Staphylococcus in milk and milk products in and around Pantnagar. Vet. World, 3(11): 495-496.

22. da Silva, Z.N., da Cunha, A.S., Lins, M.C., De AM Carneiro, L., De F Almeida, A.C. and Queiroz, M.L.P. (2001)
Isolation and serological identification of enteropathogenic Escherichia coli in pasteurized milk in Brazil isolamento e identificação sorológica de Escherichia coli enteropatogênica em leite pasteurizado. Rev. Microbiol., 35(4): 269.

23. Disassa, N., Sibhat, B., Mengistu, S., Muktar, Y. and Belina, D. (2017) Prevalence and antimicrobial susceptibility pattern of $E$. coli $\mathrm{O} 157: \mathrm{H} 7$ isolated from traditionally marketed raw cow milk in and around Asosa Town, Western Ethiopia. Vet. Med. Int., 2017(40): 7581531.

24. Sarkar, S., Ulett, G.C., Totsika, M., Phan, M.C. and Schembri, M.A. (2014) Role of capsule and O antigen in the virulence of uropathogenic Escherichia coli. PLoS One, 9(4): e94786.

25. Fratamico, P.M., DebRoy, C., Liu, Y., Needleman, D.S., Baranzoni, G.M. and Feng, P. (2016) Advances in molecular serotyping and subtyping of Escherichia coli. Front. Microbiol., 7: 1-8.

26. Tamura, K., Sakazaki, R., Murase, M. and Kosakot, Y. (1996) Identification and typing of bacteria serotyping and categorisation of Escherichia coli strains isolated between 1958 and 1992 from diarrhoeal diseases in Asia. J. Med. Microbiol., 45(???): 353-358.

27. Correa, M.G.P. and Marin, J.M. (2002) O-serogroups, eae gene and EAF plasmid in Escherichia coli isolates from cases of Bovine Mastitis in Brazil. Vet. Microbiol., 85(2): 125-132.

28. Lira, W.M., Macedo, C. and Marin, J.M. (2004) The incidence of shiga toxin-producing Escherichia coli in Cattle with Mastitis in Brazil. J. Appl. Microbiol., 97(4): 861-866.

29. Wells, J.G., Shipman, L.D. Greene, K.D., Sowers, E.G., Green, J.H., Cameron, D.N., Downes, F.P., Martin, M.L., Griffin, P.M. and Ostroff, S.M. (1991) Isolation of Escherichia coli serotype O157:H7 and other shiga-like-toxin-producing E. Coli from dairy Cattle. J. Clin. Microbiol., 29(5): 985-989.

30. Awad, W.S., El-Sayed, A.A., Mohammed, F.F., Bakry, N.M., Abdou, N.E.M. and Kamel, M.S. (2020) Molecular characterization of pathogenic Escherichia coli isolated from diarrheic and in-contact cattle and buffalo calves. Trop. Anim. Health Prod., 52(6): 3173-3185.

31. Echeverria, P., Taylor, D.N., Bettelheim, K.A., Chatkaeomorakot, A., Changchawalit, S., Thongcharoen, A. and Leksomboon, U. (1987) HeLa cell-adherent enteropathogenic Escherichia coli in children under 1 year of age in Thailand. J. Clin. Microbiol., 25(8): 1472-1475.

32. Scotland, S.M., Willshaw, G.A., Smith, H.R., Said, B., Stokes, N. and Rowe, B. (1993) Virulence properties of Escherichia coli strains belonging to serogroups O26, O55, O111 and O128 isolated in the United Kingdom in 1991 from patients with diarrhoea. Epidemiol. Infec., 111(3): 429-438.

33. Law, D. (1994) Adhesion and its role in the virulence of enteropathogenic Escherichia coli. Clin. Microbiol. Rev., 7(2): 152-173.

34. Delannoy, S., Beutin, L., Mariani-Kurkdjian, P., Fleiss, A., Bonacorsi, S. and Fach, P. (2017) The Escherichia coli serogroup $\mathrm{O} 1$ and $\mathrm{O} 2$ lipopolysaccharides are encoded by multiple O-antigen gene clusters. Front. Cell Infect. Microbiol., 7: 1-13.

35. Lacher, D.W., Gangiredla, J., Jackson, S.A., Elkins, C.A. and Feng, P.C.H. (2014) Novel microarray design for molecular serotyping of shiga toxin-producing Escherichia coli strains isolated from fresh produce. Appl. Environ. Microbiol., 80(15): 4677-4682.

36. Chaleshtori, F.S., Arani, N.M., Aghadavod, E., Naseri, A. and Chaleshtori, R.S. (2017) Molecular characterization of Escherichia coli recovered from traditional milk products in Kashan, Iran. Vet. World, 10(10): 1264-1268.

37. Garbaj, A.M., Awad, E.M., Azwai, S.M., Abolghait, S.K., Naas, H.T., Moawad, A.A., Gammoudi, F.T., Barbieri, I. and Eldaghayes, I.M. (2016) Enterohemorrhagic Escherichia coli $\mathrm{O} 157$ in milk and dairy products from Libya: Isolation and molecular identification by partial sequencing of $16 \mathrm{~S}$ rDNA. Vet. World, 9(11): 1184-1189. 
38. Kuhnert, P., Korczak, B.M., Stephan, R., Joosten, H. and Iversen, C. (2009) Phylogeny and prediction of genetic similarity of cronobacter and related taxa by multilocus sequence analysis (MLSA). Int. J. Food Microbiol., 136(2): 152-158.

39. Hasan, M.K., Momtaz, F., Foysal, M.J., Ali, M.H., Islam, K. and Prodhan, S.H. (2018) The characterization of multidrug-resistant Type 1 S-fimbriated Escherichia coli from women with recurrent urinary tract infections (RUTIS) in Bangladesh. Afr. J. Clin. Exp. Microbiol., 20(1): 25.

40. Sekizuka, T., Inamine, Y., Segawa, T. and Kuroda, M. (2019) Characterization of NDM-5-and CTX-M-55-coproducing Escherichia coli GSH8M-2 isolated from the effluent of a wastewater treatment plant in Tokyo Bay. Infect. Drug Resist., 12: 2243-2249.

41. Carrascosa, C., Millán, R., Saavedra, P., Jaber, J.R., Raposo, A. and Sanjuán, E. (2016) Identification of the risk factors associated with cheese production to implement the hazard analysis and critical control points (HACCP) system on cheese farms. J. Dairy Sci., 99(4): 2606-2616.

42. Beutin, L., Geier, D., Steinruck, H., Zimmermann, S. and Scheutz, F. (1993) Prevalence and some properties of verotoxin (Shiga-like toxin)-producing Escherichia coli in seven different species of healthy domestic animals. J. Clin. Microbiol., 31(9): 2483-2488.

43. Cobbold, R. and Desmarchelier, P. (2001) Characterisation and clonal relationships of shiga-toxigenic Escherichia coli (STEC) isolated from Australian dairy cattle. Vet. Microbiol., 79(4): 323-335.

44. Hornitzky, M.A., Vanselow, B.A., Walker, K., Bettelheim, K.A., Corney, B., Gill, P., Bailey, G. and Djordjevic, S.P. (2002) Virulence properties and serotypes of shiga toxin-producing Escherichia coli from healthy Australian cattle. Appl. Environ. Microbiol., 68(12): 6439-6445.

45. Orden, J.A., Ruiz-Santa-Quiteria, J.A., Cid, D., García, S., Sanz, R. and De La Fuente, R. (1998) Verotoxin-producing Escherichia coli (VTEC) and eae-positive non-VTEC in 1-30-days-old diarrhoeic dairy calves. Vet. Microbiol., 63(24): $239-248$.

46. Bean, A., Williamson, J. and Cursons, R.T. (2004) Virulence genes of Escherichia coli strains isolated from mastitic milk. J. Vet. Med. Ser. B Infect. Dis. Vet. Public Health., 51(6): 285-287.

47. Zschock, M., Hamann, H.P., Kloppert, B. and Wolter, W. (2000) Shiga-toxin-producing Escherichia coli in faeces of healthy dairy cows, sheep and goats: Prevalence and virulence properties. Lett. Appl. Microbiol., 31(3): 203-208.

48. Hinton, M., Linton, A.M. and Hedges, A.J. (1985) The ecology of Escherichia coli in calves reared as dairy-cow replacements. J. Appl. Bacteriol., 58(2): 131-138.

49. Jenkins, C., Pearce, M.C., Chart, H., Cheasty, T., Willshaw, G.A., Gunn, G.J., Dougan, G., Smith, H.R., Synge, B.A. and Frankel, G. (2002) An eight-month study of a population of verocytotoxigenic Escherichia coli (VTEC) in a Scottish Cattle Herd. J. Appl. Microbiol., 93(6): 944-953.

50. Fathy, H., Abdeen, E., Moustapha, E., Hussien, A.E. and Younis, G. (2019) Development of PCR and multiplex-PCR for detection of some Escherichia coli virulence genes from bovine neonates Diarrhea. J. Curr. Vet. Res., 1(1): 60-74.

51. Knutton, S., Baldwin, T., Williams, P.H. and McNeish, A.S. (1989) Actin accumulation at sites of bacterial adhesion to tissue culture cells: Basis of a new diagnostic test for enteropathogenic and enterohemorrhagic Escherichia coli. Infect. Immun., 57(4): 1290-1298.

52. Moon, H.W., Whipp, S.C., Argenzio, R.A., Levine, M.M. and Giannella, R.A. (1983) Attaching and effacing activities of rabbit and human enteropathogenic Escherichia coli in pig and rabbit intestines. Infect. Immun., 41(3): 1340-1351.

53. Hussien, H., Elbehiry, A., Saad, M., Hadad, G., Moussa, I., Dawoud, T., Mubarak, A. and Marzouk, E. (2019) Molecular characterization of Escherichia coli isolated from cheese and biocontrol of shiga toxigenic $E$. Coli with essential oils. Ital. J. Food Saf., 8(3): 8291.

54. Burgos, Y. (2010) Common origin of plasmid-encoded alpha-hemolysin genes in Escherichia coli. BMC Microbiol., 10(1): 193.

55. Adzitey, F., Setsoafia, C.K. and Teye, G.A. (2016) Antibiotic susceptibility of Escherichia coli isolated from milk and hands of milkers in Nyankpala community of Ghana. Curr. Res. Dairy Sci., 8(1):11.

56. Tadesse, D.A., Zhao, S., Tong, E., Ayers, S., Singh, A., Bartholomew, M.J. and McDermott, P.K. (2012) Antimicrobial drug resistance in Escherichia coli from humans and food animals, United States, 1950-2002. Emerg. Infect. Dis., 18(5): 741-749.

57. Geser, N., Stephan, R. and Hächler, H. (2012) Occurrence and characteristics of extended-spectrum $\beta$-lactamase (ESBL) producing Enterobacteriaceae in food-producing animals, minced meat and raw milk. BMC Vet. Res., 8: 21.

58. Ntuli, V., Njage, P.M.K. and Buys, E.M. (2016) Characterization of Escherichia coli and other Enterobacteriaceae in producer-distributor bulk milk. $J$. Dairy Sci., 99(12): 9534-9549.

59. Lyimo, B., Buza, J., Subbiah, M., Smith, W. and Call, D.R. (2016) Comparison of antibiotic-resistant Escherichia coli obtained from drinking water sources in Northern Tanzania: A cross-sectional study. BMC Microbiol., 16(1): 1-10.

60. Jajarmi, M., Fooladi, A.A.I., Badouei, M.A. and Ahmadi, A. (2017) Virulence genes, shiga toxin subtypes, major O-serogroups, and phylogenetic background of shiga toxin-producing Escherichia coli strains isolated from cattle in Iran. Microb. Pathog., 109: 274-279.

61. Abdus Sobur, M., Al Momen Sabuj, A., Sarker, R., Taufiqur Rahman, A.M.M., Lutful Kabir, S.M. and Rahman, M.T. (2019) Antibiotic-resistant Escherichia coli and Salmonella spp. associated with dairy cattle and farm environment having public health significance. Vet. World., 12(7): 984-993.

62. Shaikh, S., Fatima, J., Shakil, S., Rizvi, S.M.D. and Kamal, M.A. (2015) Antibiotic resistance and extended-spectrum beta-lactamases: Types, epidemiology, and treatment. Saudi J. Biol. Sci., 22(1): 90-101.

63. Manoharan, A., Premalatha, K., Chatterjee, S. and Mathai, D. (2011) Correlation of TEM, SHV and CTX-M extended-spectrum beta-lactamases among Enterobacteriaceae with their in vitro antimicrobial susceptibility. Indian $J$. Med. Microbiol., 29(2): 161-164.

64. Pishtiwan, A.H. and Khadija, K.M. (2019) Prevalence of BlaTEM, BlaSHV, and BlaCTX-M genes among ESBLproducing klebsiella pneumoniae and Escherichia coli isolated from thalassemia patients in Erbil, Iraq. Mediterr. $J$. Hematol. Infect. Dis., 11(1): 1-7.

65. da Silva, G.J. and Mendonça, N. (2012) Association between antimicrobial resistance and virulence in Escherichia coli. Virulence, 3(1): 18-28.

66. Iweriebor, B.C., Iwu, C.J., Obi, L.C., Nwodo, U.U. and Okoh, A.J. (2015) Multiple antibiotic resistances among shiga toxin-producing Escherichia coli O157 in feces of dairy cattle farms in Eastern Cape of South Africa. $B M C$ Microbiol., 15: 213. 